\title{
On the Integration of College English Teaching and Ideological and Political Courses From the Perspective of Intercultural Communication
}

\author{
Jingwen $\mathrm{Ma}^{1, *}$ \\ ${ }^{1}$ Foreign language department, Shandong Technology and Business University, Yantai Shandong, China, 264005 \\ *Corresponding author. Email: xssy163@163.com
}

\begin{abstract}
General Secretary Xi Jinping stressed at the National Conference on Ideological and Political Work of Colleges and Universities that all kinds of courses should follow the same path as ideological and political theory courses, and "cultivate people with virtue" should run through all links of education and teaching. The introduction of curriculum thought and politics into college English classroom is in the exploratory stage, and the combination of curriculum thought and politics with the rigidity of college English is inevitable in the concrete practice. This paper mainly discusses the integration of college English and ideological and political courses from the perspective of cross-cultural communication, and improves the strategies of integrating ideological and political courses into college English education from the following aspects: exploring cultural elements and ideological and political elements in textbooks, expanding students' cultural horizon, establishing correct values for ideological and political education and developing the fine traditional Chinese culture to cultivate culture confidence.
\end{abstract}

Keywords: College English teaching, Ideological and political courses, Intercultural communication.

\section{INTRODUCTION}

For a long time, ideological and political education in colleges and universities mainly relies on traditional ideological and political courses and inculcation from counselors, but these two ways of education have little effect.

At the 2016 National Conference on Ideological and Political Work of Colleges and Universities, Comrade $\mathrm{Xi}$ Jinping stressed that all kinds of courses should follow the same path as ideological and political theory courses, take moral education as the central link, make ideological and political education run through the whole process of education and teaching, and realize allround education. Ideological and political education in colleges and universities should make good use of the main channel of classroom teaching, and all kinds of courses should go along with ideological and political education. The 19th National Congress of the Communist Party of China once again stressed that moral education is the fundamental task of education, and ideological and political education should be strengthened in colleges and universities. The ideological and political course of college English teaching must run through the whole class. College English courses mainly teach English and Englishrelated contents. This paper discusses the integration and strategies of college English teaching and ideological and political courses from the perspective of cross-cultural communication.

College English Ideological and Political Courses under the context of Cross-cultural Communication can effectively improve the lack of native language culture and the lag of ideological cognition in college English classes, so as to cultivate students into talents needed by the era full of cultural confidence and international vision, and achieve the goal of coordinating and synchronizing ideological and political theory courses with college English and complementing each other. 


\section{WHAT ISINTERCULTURAL COMMUNICATION?}

\subsection{The Definition of Intercultural Communication}

Generally speaking, if you are dealing with foreigners (due to differences in language and cultural background), you should pay attention to and how to communicate appropriately. The cultivation of intercultural communication competence has always been the focus of college English courses. In the college English teaching syllabus, it is clearly proposed that students should have the ability to communicate and communicate in a cross-cultural context.

Intercultural communication, based on interpersonal communication, is the communication between different cultures. In the process of communication, participants should understand and accept each other's culture on the basis of their own culture, so as to achieve intercultural communication. People of every country and every nationality have their own cultural background. Crosscultural communication is to realize the cultural exchange among participants of different countries, regions and nationalities. In communication, it is an important process to realize tolerance, understanding, integration and collision among different civilizations through individual communication. College English education workers in the process of cultivating students' intercultural communicative competence, should guide students to learn to respect communication each other's cultural background, the history of other countries, and the road of development the other countries choose according to their own national conditions, so as to make college students better grasp the scale of the crosscultural communication in the process of the future study, life and work, really master cross-cultural communicative competence.

\subsection{The Necessity of Cultivating Intercultural Communication Competence}

\subsubsection{In-depth Development of the World Economy}

The pace of world economic development is faster and faster, and the trend of world economic integration is more and more obvious. Since China joined the WTO in 2002, the national economy has also developed rapidly and become the second largest economy in the world. With the development of economy, our country has strengthened.

The exchanges with the rest of the world and the cooperation in the fields of economy, culture and science and technology are increasing. But there are also frequent problems in cooperation, because of the different historical and cultural backgrounds between
Cross-cultural communication refers to the communication between native speakers and non-native speakers, as well as any communication between people with different linguistic and cultural backgrounds.

the East and the West. Different historical and cultural backgrounds, people's values, life style, religious belief and behavior habits will be different, so in cross-cultural communication, there will be some cultural conflicts. However, many of these cultural conflicts can be avoided, which requires high cross-cultural communication skills. Therefore, cultivation of the cross-cultural communication ability is necessary.

It is of great significance to promote exchanges and cooperation between East and West in the fields of economy, education, science and technology.

\subsubsection{Globalization of Education}

In 1983, Deng Xiaoping clearly put forward the concept of education internationalization, that is, education should be oriented towards modernization, the world and the future. Among these three aspects, facing the world requires us to constantly improve the level of education internationalization. In the field of education, the concept of education internationalization is also very important.

To arouse people's attention, in the outline of China's education reform and development plan, the training goal of international talents is clearly put forward, that is, to train a large number of international talents with international vision, who are familiar with international rules and can participate in international affairs and international competition. In this big world family, people face many of the same problems, such as energy, environment, ethnicity, and so on. Most of these problems require cooperation between countries. If you want to deal with different countries, you must first understand their politics, history and culture; otherwise, it will come out in communication. Therefore, cooperation between countries in different fields needs to cultivate international talents. This is also the demand of our whole society for education. The new educational concept puts higher demands on learners.

\section{FROM THE PERSPECTIVE OF INTERCULTURAL COMMUNICATION, HOW TO IMPLEMENT COLLEGE ENGLISH CURRICULUM PHILOSOPHY?}

\subsection{Focus on the Content of College English Teaching to Highlight the Cultural Knowledge in the Material}

For a long time, college English teaching has always paid attention to the inculcation of pure language 
knowledge, and both sides of English teaching are highly utilitarian. The purpose of language learning is to communicate (words and written expressions), rather than merely reciting words to enlarge their vocabulary, and mastering grammar rules and language knowledge. Language is an important carrier and reflection of culture. The two complement each other. However, according to the author's classroom survey, more than $80 \%$ of the students believe that learning English is to learn the language grammar well, and to enlarge vocabulary and so on, generally lack of the awareness that language is the cultural load and cultural learning is far more important than language learning. In the process of teaching, only the instrumental nature of language and the form of language is emphasized, while the social significance is ignored in both teaching and teaching materials.

Therefore, in the process of teaching, teachers should not only teach the practical cultural knowledge, but also make use of the cultural phenomena reflected in the textbooks to grasp the implied humanistic themes and conduct ideological and political education for students in a timely manner. Native English speakers like to get straight to the subject, while Chinese tend to detour into the subject. It's the values that determine how people interact. What seems to be the difference between the two expressions is actually the conflict between the two values. In interpersonal communication, Chinese people stress friendliness, pay attention to modesty and try to avoid confrontation. Westerners also value interpersonal relationships, but the first thing is to get things done, so they like to get to the point. Values determine the way people act and communicate. Therefore, teachers can take advantage of the situation to introduce socialist core values into the classroom and guide students to establish correct values.

\subsection{Expand College English Teaching Content and Integrate Chinese Ideological and Political Elements}

Teachers often say that students' intercultural consciousness should be cultivated while imparting cultural knowledge. What is intercultural consciousness? Intercultural consciousness includes two aspects. In the process of contact with different cultures, I have a deeper understanding of my own culture. As mentioned above, due to the particularity of English subject, the content of English course involves a large number of foreign cultures. Teachers and students can understand western political and economic system, educational system, interpersonal relationship and other aspects while learning English language. But the strong inculcation effect of English culture leads to the phenomenon of Chinese cultural aphasia. Students can freely say words related to Western food such as pizza, hamburger and chips, but they do not know the Chinese expressions such as steamed bun, baked cake and steamed bun. In response to this phenomenon, teaching materials and assessment content have begun to make corresponding changes. For example, the second edition of the New Horizon College English textbook keeps pace with The Times, adding translation exercises such as medicinal food and Confucius and Mencius to the after-class exercises, which enrich and perfect the content of the textbook and reflect the potential ideological and political education function of the textbook. For another example, the Chinese-English translation questions of the CET- 4 and CET- 6 after the reform mostly involve Chinese politics, economy, culture and life, which make up for the deficiency of Chinese ideological and political elements in the teaching content. In addition, during the course explanation, teachers can add Chinese cultural elements accordingly and create intercultural communication scenes, so that students can have a more thorough understanding of Chinese culture and view Western culture in a more rational way.

\subsection{Grasp the Current News, Timely Ideologcal and Political Education}

Current politics education is a window, which can effectively broaden the horizons of learners. Current affairs and politics themselves also provide fresh materials and important texts for ideological and political courses. Schools and teachers need to attach great importance to this class and make full use of it. For a long time, college students generally do not care about current affairs and politics, and despise ideological and political study. However, after the reform of cet- 4 and CET- 6 , students are required to pay attention to current news and social hot spots. Newspapers is to understand the social dynamics, the most direct means of social problems, the teacher in class, can be combined with the major events that took place today or social hot spots, encourage students to collect relevant media and foreign media reports, analysis discussion with students, pay attention to and accumulate cultural background, feel different culture perspective differences in news reports, to help students set up the correct value orientation.

Current politics education is not a simple reading of current politics news. For the majority of teachers, they should not only provide students with original important speeches and present hot news events, but also analyze the background and connotation of speeches and events. In particular, we should use Marxist standpoint, viewpoint and method to analyze, so that students can view and understand current affairs and politics from a theoretical perspective, and improve students' scientific thinking ability. At the same time, the content of current politics education is the current events, which is the closest object of theoretical interpretation to us. 
Teachers should not only systematically explain current affairs and politics with professional knowledge, but also keep in close contact with daily life, so that students can have more personal experience of current affairs and politics through their own lives, thus deepening their understanding and improving students' cognitive ability, critical thinking ability and theoretical literacy.

\subsection{Develop and Expand the Fine Traditional Chinese Culture to Cultivate Culture Confidence}

Yu Qiuyu, a cultural scholar, put forward in What is Culture: "Culture is an ecological community containing spiritual values and lifestyle. It creates a collective personality through accumulation and guide." When culture becomes a collective personality, it also condenses into the soul of the nation. As Comrade $\mathrm{Xi}$ Jinping wrote in 19 Major newspapers, "Culture is the soul of a country and a nation. Culture can reinvigorate a country. No high level of cultural confidence, no cultural prosperity, there will be no great rejuvenation of the Chinese nation." This article mentions the traditional culture is the accumulated spiritual wealth in people's heart through the potential influence of literature and art, ideology and folk customs, expressing in a relatively stable way of thinking and aesthetic taste. It is the accumulated inner civilization in the survival of this nation and it has a rather persistent power, directly or indirectly, consciously or unconsciously influences and dominates the people of today from content to form, from moral standards to modes of thought. Advanced socialist culture integrates fine traditional Chinese culture and revolutionary literature. The essence of culture has realized the docking of values and western culture and created a brilliant era of advanced socialist culture with Chinese characteristics. Advanced socialism culture provides a theoretical foundation for cultural confidence and consolidates its material foundation. It has implanted the motivation gene of selfconfidence and realized the open and inclusive attitude of self-confidence. I am sure that our culture can only be recognized and won by others. Only affirmation from others can realize the value of our culture and realize our culture influence. The "Chinese fever" and "Confucius Fever" in recent years are enough to illustrate our cultural values and ideas are shared by people in most countries around the world.

\section{CONCLUSION}

It is not a day's work to realize the reform of college teaching aiming at "curriculum thought and politics". Language is the carrier of culture. Taking cultural learning as the entry point of "classroom thinking and politics" in college English is in line with the general Secretary's point of “correctly understanding Chinese characteristics and international comparison, comprehensively and objectively understanding contemporary China and viewing the outside world". However, how to give full play to the ideological and political education function of college English teaching is still a topic worth discussing and pondering in the future.

\section{ACKNOWLEDGMENTS}

Fund project: Education Reform Project of Shandong Institute of Business and Technology in 2020(project number: 11688202044).

\section{REFERENCES}

[1] Cenoz, Jasone; Gorter, Durk. Teaching English through pedagogical translanguaging $[\mathrm{J}]$. World Englishes, 2020, 39(02):300-311.

[2] Hung, Hsiu-Ting. Flipping the classroom for English language learners to foster active learning [J]. Computer Assisted Language Learning,2015, 28(01):81-96.

[3] Tseng, Jun-Jie; Cheng, Yuh-Show. How pre-service English teachers enact TPACK in the context of web-conferencing teaching: A design thinking approach [J]. Computers \& Education, 2019, 128(01):171-182.

[4] Vattoy, Kim-Daniel; Smith, Kari. Students' perceptions of teachers' feedback practice in teaching English as a foreign language [J]. Teaching and Teacher Education, 2019, (10):260268.

[5] Xi Jinping: The Governance of China (Volume 2)[M].Beijing: Foreign Languages Press, 2017.

[6] At the National Conference on Ideological and Political Work of Colleges and Universities, Xi Jinping stressed that ideological and political work should be carried through the whole process of education and teaching to create a new situation for the development of China's higher education [N]. China Daily, 2016- 12-09 (1).

[7] Opinions of the CPC Central Committee and the State Council on Strengthening and Improving Ideological and Political Work in Colleges and Universities under the New Situation [R].2016.

[8] Qi Yankui. Theoretical Consideration on curriculum ideological and political Construction in colleges and universities under the background of full curriculum education [J]. Heilongjiang Higher Education Research, 2020, 38, (01):124-127.

[9] Cui Ge. Exploration and Practice on the Construction of "curriculum thought and Politics" in Foreign language under the pattern of "Grand thought and Politics" [J]. Guide to Ideological and Theoretical Education, 2019, (07):138-140. 